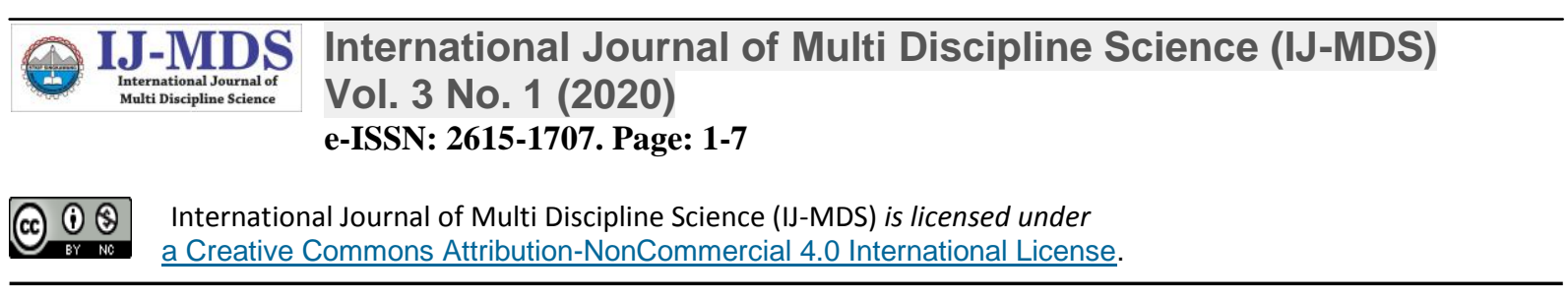

\title{
Implementation of Group Guidance Model to Improve Students' Responsibilities in Learning Activities in Class XI IPS2
}

\author{
Sri Wahyuni \\ SMA Negeri 1 Wirosari, Grobogan, Indonesia \\ sriwahyuni832015@gmail.com
}

\begin{tabular}{ll}
\hline \hline Keywords: & ABSTRACT \\
Group Guidance Model, & This study aims to improve the students' responsibilities in \\
Students Responsibilities, & following learning activities in class XI IPS2 by implementing \\
Learning Activities & the group guidance model. The population in this study were \\
all students of class XI IPS2 SMA Negeri 1 Wirosari Academic \\
Year 2018/2019. The sample was 12 students who have a \\
problem with low student responsibility in following learning \\
activities in class XI IPS2. The data collection method in this \\
study used the observation method to reveal data about \\
increasing students' responsibilities during group guidance \\
activities and students' learning activities. The data analysis \\
used descriptive analysis. The results showed that the students' \\
responsibilities in following learning activities in class XI IPS2 \\
by implementing the group guidance model increased very \\
significantly. This could be shown from the result of the initial \\
condition of the students' responsibilities in following learning \\
activities class XI IPS2 by 0\%. In cycle one there was an \\
increase in students' responsibilities by $46 \%$.
\end{tabular}

\section{INTRODUCTION}

The problem of low responsibility in participating in learning activities of students of class XI IPS2 in SMA Negeri 1 Wirosari received enough attention from all parties. This situation affects the course of education in schools that are often hampered. This fact could be seen from the initial observations with the results: often ditching $2 \%$, often late for school $20 \%$, often permission to leave learning activities $25 \%$, not making homework more than $35 \%$, late collecting more than $40 \%$ assignments, not carrying books/assignments according to schedule $15 \%$ and do not pay attention to lessons when learning activities is more than $45 \%$, and cheating on tests $65 \%$.

Various factors that influence the low level of responsibility among students of class XI IPS2 in SMA Negeri 1 Wirosari included: poor attention of parents because they are busy with economic affairs, parents who are too spoiled or too authoritarian, parents divorce, development of electronic media and influence environment.

The condition of the low responsibility of participating in learning activities among students affects the course of the teaching-learning process in schools as well as the personal qualities of students so that this will affect the human resources produced. According to Soedarsono (2006), responsibility was a very urgent matter in shaping one's character. Someone who has good responsibilities tends to 
be more qualified and more easily accepted by many people. Because they tend to have the mental courage to always learn from the risks, difficulties, and problems they face. Someone who has the potential in the form of intelligence, intelligence, and skills, if he does not have a life skill in the form of responsibility has a low bargaining price in the community and employment. This means that people rarely want to exploit this potential. Therefore the problem of the low level of responsibility for participating in the learning activities of Class XI IPS2 students in SMA Negeri 1 Wirosari is an important issue.

Based on the description above, the problem formulation is as follows: Can the guidance service using the group guidance model increase the responsibility of participating in learning activities in class XI IPS2 students in SMA Negeri 1 Wirosari Even Semester Academic Year 2018/2019? If there is an increase in responsibility, how much will it increase?. The purpose of this study is to know and describing the level of responsibility of students in participating in learning activities with the group guidance model in Class XI IPS2 SMA Negeri 1 Wirosari Even Semester Academic Year 2018/2019.

\section{LITERATURE REVIEW}

\section{Definition of Responsibility}

According to Pam Schiller and Tamera Bryant in Astuti (2005: 16), responsibility was the behavior that determines how we react to situations, which requires some kind of moral decision. Responsibility, according to Adiwiyoto (2001: 2), was to make appropriate and effective decisions, it is proper to determine the best choices within the limits of social norms and expectations that are generally given, to enhance positive human relations, safety, success, and their welfare.

Meanwhile, according to Soekanto (1992), responsibility was a consultation of actions against a particular party. Furthermore, Soedarsono (2006) said that a person's character can be formed by giving responsibility. Starting from the study of theory as mentioned above, the writer can conclude that responsibility is the willingness to be obliged to bear moral and effective decision making as a reaction to the situation.

\section{Understanding Learning Activities}

Budiningsih (2005: 7) in the Learn and Learning book argued that learning activities are delivery of subject matter or knowledge by a teacher to students as well as regulating the environment so that students learn so that students get broader knowledge or insight and learning process controlled by the student himself and not by the teacher. Hamalik (2006: 162) argued that learning activities are the process of interaction between the teacher and students to achieve learning objectives, which take place in a particular location within a certain time unit period as well.

While Andrian (2004: 18) explained that learning activities involve teachers (educators), students, learning objectives, learning content, teaching methods, media, and learning evaluation. From some opinions, it can be concluded that learning activities are a process of interaction between teacher and student which will be measured by the process of learning evaluation and efforts to achieve learning objectives that take place in a certain location and period.

\section{Understanding the Responsibilities of Following Learning Activities}

The school education pathway consisted of formal, non-formal and informal education which can complement and enrich each other (UU, 2003). For students having learning assignments that must be carried out. Students must make decisions correctly so that the implementation of learning activities can be accounted for.

Learning activities is a process that cannot be separated from schools as formal education providers. So that following the learning activities with full responsibility by students is necessary for the smooth 
running of education in schools in general and the formation of positive character for students in particular.

Adiwiyoto (2001: 89) argued that responsible individuals are: doing routine tasks without being told, being able to explain what they are doing, not blaming others excessively, being able to make choices, being able to work happily, being able to make decisions who are different from others, have interests that he elaborates on, respect and respect the rules, can concentrate on the task, do what he says he will do and admit mistakes without made up excuses.

Based on the theoretical study as mentioned above, it can be concluded that the responsibility of participating in student learning activities is the willingness to be obliged to bear moral and appropriate decision making as a reaction to situations of learning or to pay attention in a process of interaction between teacher and student where will be measured the learning evaluation process and efforts to achieve learning objectives that take place in a certain location and period. By paying attention to the responsibilities of participating in learning activities as follows: (1) conducting routine learning tasks, (2) determining learning activities in class, (3) obeying the rules of learning in class, (4) Having a strong interest in participating in learning activities.

\section{Group Guidance Model}

The group guidance model is a service that helps students in personal development, social relationship skills, learning activities, career/position, and decision making, as well as carrying out certain activities through group dynamics. Group guidance is a process of giving assistance given by the supervisor to some counselees/clients at the same time with the amount can vary between 4 people to 8 people can also be between 10 people to 15 people.

Group guidance is carried out by animate group dynamics in discussing various things that are useful for the personal development of students, prevention, and alleviation of problems that are members of group guidance. As a material for students' personal development, prevention and alleviation of problems, group guidance can discuss actual and important issues that develop in the community relevant to group problems. Through the discussion of the actual problems referred to, each member of the group guidance can get enlightenment about a problem and the possibility of its application to themselves. Each group guidance participant can take the best attitude in acting based on an understanding. In other words, students can work on a particular action based on the knowledge that has been mastered.

1. Purpose and Function of Group Guidance Services

Group guidance is intended so that group members jointly gain an understanding of various information about the topics discussed sourced from the group leader or group members.

2. Principles in Group Guidance

The principles that need to be considered in group guidance are volunteerism, tolerance, and confidentiality.

3. Discussion Topics in Group Guidance

Topics covered in group guidance are issues or problems that are outside of the general group members who have seen, read and heard from various media.

4. Stage and Steps for Group Guidance Implementation

a. Formation Stage

After the group is formed, the group leader starts the activity at the designated place.

b. Transition Stage

In the transition stage, the group leader explains the topics to be discussed.

c. Activity Stage

The topic raised by the group leader is then discussed thoroughly by all group members.

d. Termination Stage

In the termination stage the group leader provides information that the activity will end, members are allowed to convey the impressions of the activities that have been carried out, the 


\section{IJ-MDS International Journal of Multi Discipline Science (IJ-MDS) \\ Vol. 3 No. 1 (2020) \\ e-ISSN: 2615-1707. Page: 1-7}

group leader asks the possibility of the activity to be followed up, group members are allowed to convey messages and hopes at the next meeting, The activity was closed with a thank you by the group leader and ended with joint prayer.

Based on previous research theoretical studies that have been described previously, researchers can arrange the following action hypotheses: Guidance services with a group guidance model can improve the responsibility of XI IPS2 students in SMA Negeri 1 Wirosari.

\section{METHOD}

In this study using the Guidance Counseling Action Research design, which consists of 2 cycles or more and each cycle consists of 4 main activities, namely: planning, action, observation, reflection. The workflow according to Kemmis and Mc. Taggart in Aqib (2006: 6) could be described in Fig 1.

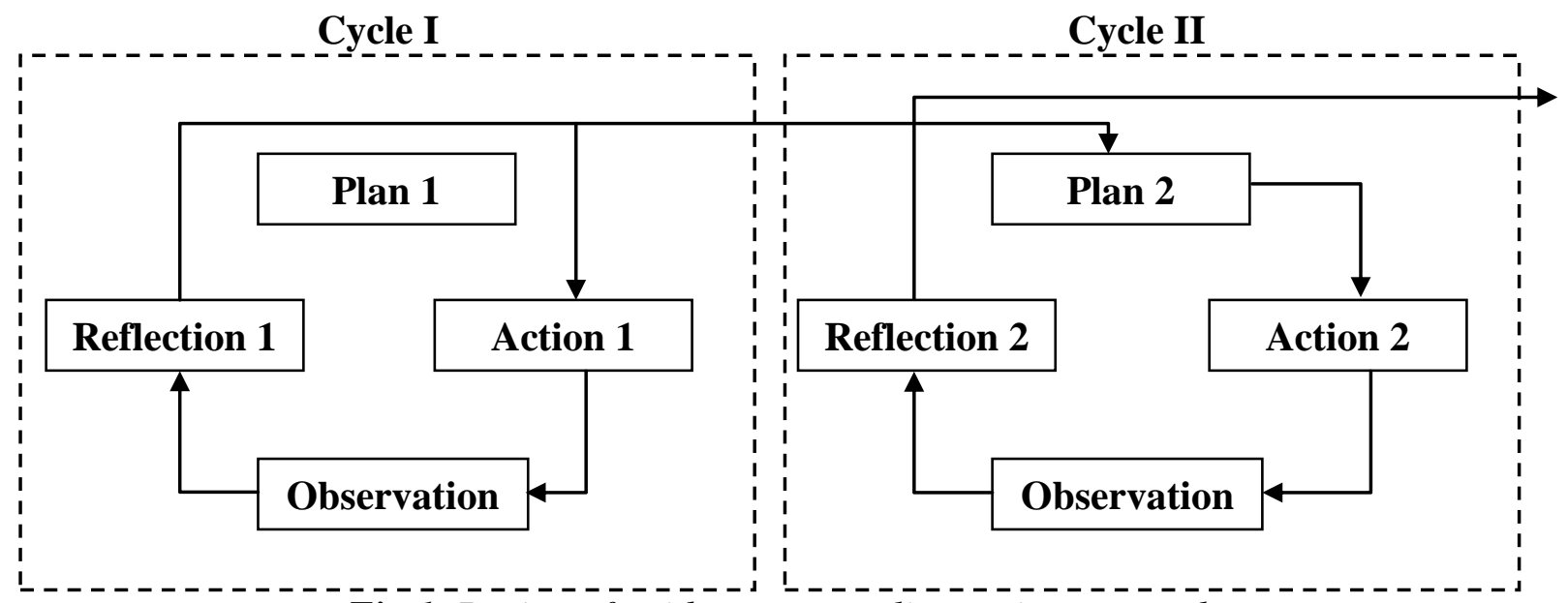

Fig 1. Design of guidance counseling action research

\section{Research Subject}

The research subjects were students of class XI IPS2 of SMA Negeri 1 Wirosari in the academic year 2018/2019 who often violated school rules. To maximize the results of the service and meet the ideal number of participants in group guidance, 12 students were chosen who had the responsibility of participating in learning activities. The research involved two tutors to become observers/collaborators.

This research was conducted at SMA Negeri 1 Wirosari, which is located at Jalan Raya No. 123, Kelurahan Kunden, Wirosari District, Grobogan Regency. The research period starts in November 2018 until April 2019. In this study, the techniques or methods used are teacher observation, student observation during the activity and observation of the level of student responsibility during the study and interview.

In this study the data analysis uses "Interactive model" analysis developed by Miles and Huberman in Aqib (2006: 108) with the following steps:

1. Data collection

2. Data Reduction

3. Describe/interpret data (Data Display)

4. Conclusion (Conclusion Drawing Verification).

Furthermore, the presentation technique is in the form of descriptive qualitative, meaning that the researcher describes the data obtained to then conclude. 


\section{Performance Indicator}

1. Students are interested in the material delivered in information services.

2. There is a change in students' attitudes in attending information services in class.

3. Increased student responsibility in following the lessons.

\section{RESULTS AND DISCUSSION}

The problem of low responsibility in participating in learning activities of students of class XI IPS2 in SMA Negeri 1 Wirosari received enough attention from all parties. This situation affects the course of education in schools that are often hampered. The condition of the low responsibility of participating in learning activities among students affects the course of the teaching-learning process in schools as well as the personal qualities of students so that this will affect the human resources produced.

Based on the report data from the teacher subject matter data of previous students, as many as 24 students of class XI IPS2 have the responsibility of participating in learning activities that are concerned, and 12 students have been selected to attend the Group Guidance service. The researcher tries to present a new method that is expected to improve student responsibility in participating in learning activities through group guidance activities. This can be seen through the results of this class action research that consists of planning, action, observation, and reflection.

\section{Cycle 1 Results}

Action Planning 1

1) Create a group guidance service unit.

2) Make a teacher observation guide to see the teacher's activities in carrying out group guidance.

3) Make observation guidelines for students while following group guidance and when following learning activities.

\section{Implementation of Actions 1}

1) The teacher supervising the researcher provides information to students about organizing group guidance.

2) The research teacher advises the topic to be discussed in group guidance.

3) The teacher supervising the researcher carries out group guidance.

4) The teacher gives material about the responsibilities of participating in learning activities that will be discussed in group guidance activities.

5) Teachers and students conduct discussions and questions and answers about the topics discussed.

\section{Observation and Interpretation}

From the results of observations during group guidance and interviews conducted after participating in service implementation, the following results are obtained: the number of students who have the responsibility of participating in student learning activities is low as many as 5 students or around $41.7 \%$ of students do not do the task and as many as 6 students or about $50 \% .4$ students or $33.3 \%$ of students did not learn according to the lessons in progress and 7 children or $58.3 \%$ of students did not bring learning equipment following the lessons in progress. A total of 6 students or around $50 \%$ of students do not enter class on time and 3 students or $25 \%$ of students do not stay in class until completion. 6 students or $50 \%$ of students did not concentrate while attending the lesson, 3 students or $25 \%$ do not follow the whole series of learning activities in class and 7 students or $58.3 \%$ enthusiastic when attending the lesson. From the above data, it can be concluded that there has been an increase in the responsibility of participating in students' learning activities through group counseling activities, although it has not been satisfactory. 


\section{Reflection on Actions 1 (The results are the basis for planning the next cycle if the results are not good)}

The results of discussions with collaborators are used to find out what has been done and achieved in the implementation of group guidance, and at the same time is a way to find out the shortcomings of group guidance service actions that have been implemented. By knowing the deficiencies in the previous group guidance service action, which is in cycle I, which we can see from the data of teacher and student observations by collaborators during the implementation of Group Guidance services, it can be planned for action renewal for the second cycle. These deficiencies include increasing game hours so students are not bored and group dynamics are increasing, adding information so students understand the importance of learning. To get maximum results, the researchers continued the research again in cycle II.

\section{Cycle II Results}

This class action research procedure consists of planning, action, observation, and reflection.

\section{Action Planning II}

1) Create a group guidance service unit.

2) Make a teacher observation guide to see the teacher's activities in carrying out group guidance.

3) Make observation guidelines for students while following group guidance and when following Learning activities.

\section{Implementation of Actions II}

1) The teacher supervising the researcher provides information to students about organizing group guidance.

2) The research teacher advises the topic to be discussed in group guidance.

3) The teacher supervising the researcher carries out group guidance.

4) The teacher gives material about the responsibilities of participating in learning activities that will be discussed in group guidance activities.

5) Teachers and students conduct discussions and questions and answers about the topics discussed.

\section{Observation and Interpretation}

The number of students who have the responsibility of participating in student learning activities is low as many as 0 students or around $0 \%$ of students do not do the task and as many as 0 students or about $0 \%$. 0 students or $0 \%$ of students do not learn according to the lessons in progress and 0 children or $0 \%$ of students do not bring learning equipment following the lessons in progress. A total of 0 students or around $0 \%$ of students do not enter class on time and 0 students or $0 \%$ of students are not in class until completion. 1 student or $8.3 \%$ of students did not concentrate while attending the lesson, 0 students or $0 \%$ do not follow the whole series of Learning activities in class and 1 student or $8.3 \%$ enthusiasm when attending lessons. From the above data, it can be concluded that there has been an increase in responsibility for participating in significant student learning activities through group guidance activities.

\section{Reflection on Action II (The results are the basis for planning the next cycle if the results are not good)}

The results of the study in the second cycle were very satisfying and maximal, therefore the researcher did not proceed to the next cycle.

\section{Discussion (Initial Conditions, Cycle I, and Cycle II)}

From the results of research in the first cycle and the second cycle can be seen a significant increase. In the initial conditions, all students committed all violations, but after attending the Cycle I Guidance Group service, some students had reduced violations in participating in learning activities. After following the group II guidance service, there is only 1 student who committed a violation, namely fewer students concentrate during the lesson and lack of enthusiasm when following the lesson. This 


\section{IJ-IMDS International Journal of Multi Discipline Science (IJ-MDS)}

Vol. 3 No. 1 (2020)

e-ISSN: 2615-1707. Page: 1-7

means that the implementation of group guidance services can increase student responsibility in participating in learning activities at school.

\section{CONCLUSION AND SUGGESTION}

\section{Conclusion}

The responsibility of participating in class XI IPS2 student learning activities in SMA Negeri 1 Wirosari in 2018/2019 through group guidance increased significantly. This can be shown from the results of the initial conditions of the responsibility of class XI IPS2 students in participating in learning activities by $0 \%$. In cycle one there was an increase in student responsibility by $46 \%$. While in the second cycle is increased to $98.1 \%$.

\section{Suggestion}

The researcher invites fellow teachers as student guides to using group guidance to increase student responsibility in participating in learning activities.

\section{REFERENCES}

Adiwiyoto, Anton. (2001). Melatih Anak Bertanggung Jawab. Jakarta: Mitra Utama. Andrian. (2004). Metode Mengajar Berdasarkan Tipologi Peserta Didik. PPs UNY.

Aqib, Zainal. (2006). Penelitian Tindakan Kelas untuk Guru. Bandung: YramaWidya.

Astuti, Chatarina Puji. (2005). Pengaruh Bimbingan Orang Tua terhadap Tanggung Jawab Belajar Siswa Kelas IV SD Pangudi Luhur Don Bosko Semarang Tahun Pelajaran 2003/2004. Skripsi. Semarang: Universitas Negeri Semarang. Tidak Dipublikasikan.

Budiningsih, A. (2005). Belajar dan Pembelajaran. Jakarta: PT. Rineka Cipta.

Hamalik, Oemar. (2006). Proses Belajar Mengajar. Bandung: BumiAksara.

Soedarsono, Soemarno. (2006). Character Building (membentuk watak). Jakarta: Elex Media Komputindo.

Soekanto, Soerjono. (1992). Kamus Sosiologi. Jakarta: PT Raja Grafindo Persada.

UU. (2003). Undang-Undang Republik Indonesia Nomor 20 Tahun 2003 tentang Sistem Pendidikan Nasional. Jakarta: Presiden RI. 